\title{
Low T2-star (T2*) Signals in cardiac MR imaging in patients with dilated cardiomyopathy and sarcoidosis
}

\author{
Yumiko Kanzaki ${ }^{1 *}$, Masako Yuki ${ }^{2}$ Nobukazu Ishizaka ${ }^{1}$ \\ From 18th Annual SCMR Scientific Sessions \\ Nice, France. 4-7 February 2015
}

\section{Background}

T2 star (T2*)-weighted MR imaging can be utilized to semi-quantitatively analyze tissue iron content. Excessive cardiac iron may aggravate cardiac performance, however, little is known about the $\mathrm{T} 2 *$ signal intensity in myopathic heart. We analyzed $\mathrm{T} 2$ * signal intensity in primary and secondary cardiomyopathy.

\section{Methods}

We enrolled 11 non-cardiomyopathic and 93 cardiomyopathic patients with following diagnoses: hypertensive or hypertrophic cardiomyopathy $(\mathrm{n}=22)$, dilated cardiomyopathy $(n=28)$, sarcoidosis $(n=13)$, old myocardial infarction $(\mathrm{n}=7)$, and other form of cardiomyopathy $(\mathrm{n}=23)$. Using 3-Teslar cardiac MRI (SignaHDxt, GE medical), $\mathrm{T}^{*}$ signal intensity in the cardiac ventricular septum and hepatic parenchyma were measured.

\section{Results}

Compared with the cardiac $\mathrm{T} 2 *$ values in non-cardiomyopathic group $(25.7 \pm 5.7 \mathrm{msec})$, those in hypertrophic cardiomyopathy or hypertensive cardiomyopathy (24.6 $\pm 7.9 \mathrm{msec}$ ) did not differ significantly, however, those in the dilated cardiomyopathy $(20.6 \pm 5.6 \mathrm{msec}, \mathrm{P}<0.01)$ and sarcoidosis $(18.0 \pm 3.2 \mathrm{msec}, \mathrm{P}<0.01)$ were significantly lower. On the other hand, liver $\mathrm{T} 2^{*}$ values, as well as serum ferritin and iron concentrations, in patients with dilated cardiomyopathy or those with sarcoidosis did not differ those in the non-cardiomyopathic group.

${ }^{1}$ Cardiology, Osaka Medical College, Osaka, Japan

Full list of author information is available at the end of the article

\section{Conclusions}

Cardiac $\mathrm{T}^{*}$ signal intensity was lower in the heart of dilated cardiomyopathy and sarcoidosis. Whether excessive iron in these forms of cardiomyopathy aggravates cardiac performance through generating noxious reactive oxygen species needs further investigation.

\section{Funding}

N/A.

\section{Authors' details}

'Cardiology, Osaka Medical College, Osaka, Japan. ${ }^{2}$ Radiology, Osaka medical college, Osaka, Japan.

Published: 3 February 2015

doi:10.1186/1532-429X-17-S1-Q73

Cite this article as: Kanzaki et al.: Low T2-star (T2*) Signals in cardiac MR imaging in patients with dilated cardiomyopathy and sarcoidosis. Journal of Cardiovascular Magnetic Resonance 2015 17(Suppl 1):Q73.

Submit your next manuscript to BioMed Central and take full advantage of:

- Convenient online submission

- Thorough peer review

- No space constraints or color figure charges

- Immediate publication on acceptance

- Inclusion in PubMed, CAS, Scopus and Google Scholar

- Research which is freely available for redistribution 